Sains Malaysiana 50(4)(2021): 1077-1087

http://doi.org/10.17576/jsm-2021-5004-18

\title{
Prestasi Mekanik Korona Zirkonia Monolitik melalui Kaedah Unsur Terhingga
}

(Mechanical Performance of Monolithic Zirconia Crown through Finite Element Methods)

\author{
Mohamad Najib Mohd Kasmani, Noor Faeizah Amat, Meor IqRam Meor Ahmad \& Andanastuti \\ MUCHTAR*
}

ABSTRAK

Dalam kajian ini, prestasi mekanik korona zirkonia monolitik bagi aplikasi dental dikenal pasti melalui analisis kaedah unsur terhingga (FEM) iaitu analisis terma dan analisis beban mekanikal. Zirkonia ialah bahan restorasi dental yang semakin meluas digunakan kerana mempunyai sifat bioserasi dan estetik yang baik berbanding bahan lain. Oleh itu, tujuan utama kajian ini adalah untuk mengenal pasti ketebalan korona zirkonia monolitik yang mampu menahan kitaran beban yang dikenakan, mengenal pasti kesan kitaran perubahan suhu pada struktur korona dengan ketebalan berbeza dan mengenal pasti perhubungan antara kitaran beban dan kitaran terma pada korona gigi zirkonia monolitik melalui simulasi FEM. Model 3D reka bentuk berbantu komputer (CAD) korona zirkonia monolitik dengan ketebalan 0.5, 0.6, 0.7, 0.8 dan $0.9 \mathrm{~mm}$ telah dijana melalui kaedah imbasan tomografi berkomputer. Kitaran beban yang dikenakan adalah 300, 400, 500, 600, 700 dan $800 \mathrm{~N}$ manakala kitaran terma pula dikenakan perubahan suhu antara 5 sehingga $55^{\circ} \mathrm{C}$. Justeru, gabungan analisis ini melalui simulasi FEM menggambarkan persekitaran mulut yang lebih realistik dan kompleks terhadap prestasi korona zirkonia monolitik bagi aplikasi dental. Hasil simulasi FEM mendapati bahawa ketebalan 0.8 dan $0.9 \mathrm{~mm}$ merupakan ketebalan yang paling selamat kerana menerima tekanan Von Mises paling sedikit berbanding ketebalan lain. Namun, ketebalan $0.5 \mathrm{~mm}$ juga masih mampu menahan beban mekanikal dan perubahan suhu yang dikenakan tetapi berisiko untuk mengalami keretakan.

Kata kunci: Beban kitaran; kaedah unsur terhingga; kesan ketebalan; korona dental; zirkonia monolitik

\section{ABSTRACT}

In this study, the mechanical performance of monolithic zirconia crowns for dental applications was identified through the finite element method (FEM) from thermal and mechanical load analyses. Zirconia is a widely used dental restoration material because of its high biological compatibility with the oral cavity environment and good esthetic properties over other materials. Therefore, this study aimed to identify the thickness of the monolithic zirconia crowns that can withstand the load exerted, the effects of temperature changes on crown structures with different thicknesses, and the relationship between mechanical cyclic loads and thermal cyclic changes of the monolithic zirconia crowns through FEM simulation. The 3D computer-aided design monolithic zirconia crowns with a thickness of 0.5, 0.6, 0.7, 0.8, and $0.9 \mathrm{~mm}$ were produced through computed tomography. Cyclic loads were applied between 300 and $800 \mathrm{~N}$, whereas thermal cycles were subjected between 5 and $55^{\circ} \mathrm{C}$. Hence, the combination of this analysis through FEM simulation will illustrate a realistic and complex oral environment of the monolithic zirconia crown performance for dental application. FEM simulation results showed that the thickness of 0.8 and $0.9 \mathrm{~mm}$ was the safest as the monolithic zirconia crowns with the aforementioned thickness values received the minimum Von Mises stress compared with those with other thickness values. However, monolithic zirconia crowns with the thickness of $0.5 \mathrm{~mm}$ were still able to withstand the mechanical loads and temperature changes that were imposed but were at risk for cracks.

Keywords: Cyclic load; dental crown; finite element method; monolithic zirconia; thickness effect

\section{PENGenalan}

Restorasi dental merupakan satu kaedah rawatan pemulihan bagi gigi yang telah rosak, patah atau tertanggal agar dapat kembali kepada fungsi, bentuk dan penampilan gigi yang asal. Salah satu contoh restorasi dental yang popular untuk rawatan pemulihan gigi adalah korona (crown). Korona adalah prostesis tetap yang dicantumkan pada gigi yang telah kehilangan 
sebahagian struktur atau disambungkan pada implan bagi gigi yang telah kehilangan semua strukturnya dengan menggunakan simen dental. Secara amnya terdapat tiga jenis korona yang dikategorikan berdasarkan jenis bahan iaitu logam, logam terlakur porselin (PFM) dan seramik penuh. Pada masa kini, korona jenis logam amat jarang digunakan berikutan ia tidak dapat menampilkan ciri estetik seperti gigi semula jadi serta boleh memberi kesan reaksi alergi kepada pesakit yang mempunyai alahan terhadap logam. Korona jenis PFM dan seramik penuh pula lebih menjadi pilihan untuk rawatan berikutan ciri estatik yang lebih baik berbanding korona logam (Daud et al. 2017). Kedua-dua korona ini direka secara sistem dwilapisan, iaitu terdiri daripada lapisan teras dalam dan venir luar. Sebagai contoh korona jenis seramik penuh, bahan terasnya terdiri daripada seramik yang mempunyai kekuatan mekanik yang baik iaitu zirkonia, manakala venir luar adalah daripada seramik porselin yang berfungsi menampilkan ciri estetik seperti gigi sebenar.

Terkini, korona jenis zirkonia monolitik pula telah diperkenalkan dan ia semakin mendapat perhatian kerana memiliki kekuatan mekanik yang cemerlang berbanding bahan lain, di samping mempunyai ciri estetik yang menghampiri ciri gigi sebenar (Amat et al. 2020; Dal Piva et al. 2018). Uniknya, korona monolitik ini dibangunkan daripada struktur kukuh dan teguh yang diperbuat daripada satu bongkah bahan sahaja iaitu zirkonia. Proses penyediaan korona monolitik juga dikatakan lebih ringkas serta menjimatkan masa kerana tidak memerlukan pengubahsuaian pada ketebalan rangka kerja bahan teras serta tidak memerlukan lagi proses pelapisan venir (Mundhe et al. 2015). Di samping itu, ia juga mempunyai ketepatan dimensi yang lebih baik berbanding sistem seramik bervenir, selain dapat mengatasi masalah penyerpihan dan kehausan pada venir korona dwilapisan akibat daripada kekuatan mekaniknya yang lemah (Nasrin et al. 2018; Preis et al. 2016).

Prestasi mekanik zirkonia untuk aplikasi pergigian dilaporkan antara yang cemerlang dalam beberapa kajian terdahulu (Denry \& Kelly 2008; Rekow et al. 2011). Namun begitu, zirkonia memiliki kecenderungan untuk mengalami degradasi apabila terdedah kepada persekitaran yang lembap (LTD) untuk jangka masa yang lama dan apabila dikenakan beban yang tinggi secara berulang-ulang (Flinn et al. 2017; Kohorst et al. 2008). Tambahan lagi, zirkonia bersifat putih legap atau kurang lutcahaya dan hal ini menjadikan ciri estatiknya kurang menarik berbanding seramik porselin (Wang et al. 2013). Pelbagai kajian telah dijalankan bagi mengatasi keduadua masalah LTD dan lutcahaya ini, termasuk kajian yang dijalankan oleh kumpulan kami iaitu berkenaan penghasilan blok zirkonia terbaharu menerusi gabungan teknik berkoloid dan penekanan isostatik sejuk (CIP) (Amat et al. 2018). Zirkonia terbaharu yang dihasilkan ini telah menunjukkan prestasi mekanik yang baik walaupun telah menjalani ujian penuaan, iaitu apabila dikenakan pada persekitaran lembap (Aboras et al. 2019; Amat et al. 2019). Selain itu, penggunaan serbuk zirkonia bersaiz nano berupaya membantu meningkatkan ciri kelutcahayaan zirkonia melalui formulasi gabungan kedua-dua teknik tersebut, seterusnya berpotensi menjadi alternatif kepada bahan korona monolitik yang sedia ada di pasaran.

Namun begitu, masih banyak lagi kajian perlu dijalankan bagi memastikan prestasi korona zirkonia monolitik terbaharu ini berada pada tahap prestasi yang maksimum. Lebih-lebih lagi aplikasi korona terletak dalam persekitaran mulut yang kompleks, yang mana kajian mengenai keupayaan mekanik dan fizikal korona dalam menjalankan fungsi aplikasinya secara realistik agak sukar dijalankan. Selain itu, reka bentuk geometri korona yang kompleks, yang mana perlu menyerupai anatomi gigi asli dari segi alur pada permukaan kunyahan gigi (oklusi) iaitu pada gigi geraham, boleh menyumbang kepada kegagalan struktur (Carrabba et al. 2017; Zhang et al. 2016). Berdasarkan kajian Carrabba et al. (2017), ketebalan korona zirkonia juga mampu mempengaruhi sifat kelutcahayaan serta menjadi faktor kepada ciri estetik restorasi tersebut. Semakin menipis zirkonia maka semakin tinggi kelutcahayaan yang dicapai. Namun jika ketebalan zirkonia terlalu rendah semata-mata untuk mencapai nilai estetik yang baik, perkara ini mungkin akan merisikokan kekuatan mekanik zirkonia. Hal ini ditambah dengan faktor suhu persekitaran dalam mulut yang berubah-ubah antara 5 hingga $55^{\circ} \mathrm{C}$, yang boleh meningkatkan tahap kelesuan pada struktur zirkonia seterusnya mengalami keretakan (Flinn et al. 2017).

Berikutan hal tersebut, analisis melalui kaedah unsur terhingga (FEM) telah mula dipraktikkan dalam beberapa kajian terdahulu bagi menilai keupayaan bahan untuk aplikasi restorasi dental (Wakabayashi et al. 2018). Kaedah FEM merupakan salah satu teknologi reka bentuk berbantu komputer/pembuatan berbantu komputer (CAD/CAM) yang menjadi alternatif kepada penyelesaian masalah kejuruteraan secara kaedah berangka. Kebanyakan analisis yang dijalankan menggunakan FEM dalam bidang pergigian lebih tertumpu kepada analisis pengagihan tekanan pada gigi (Lan et al. 2016; Miura et al. 2018). Namun begitu, terdapat analisis FEM lain yang dilihat penting untuk aplikasi restorasi pergigian, iaitu analisis pengembangan terma, tekanan pada oklusi dan reka bentuk geometri atau ketebalan (Anami et al. 2015). Oleh yang demikian, faktor yang mempengaruhi kelesuan bahan dan tekanan maksimum yang mampu ditanggung oleh korona zirkonia monolitik terbaharu ini 
perlulah dikaji bagi memastikan bahan tersebut mencapai tahap sifat mekanik yang baik. Sehubungan itu, kajian ini menfokuskan prestasi mekanik korona gigi zirkonia monolitik pada ketebalan yang berbeza untuk analisis kelesuan mekanikal. Seterusnya, kajian ini juga melibatkan analisis kesan perubahan suhu dalam persekitaran mulut dan beban mekanik yang dikenakan terhadap kekuatan mekanik korona zirkonia.

\section{BAHAN DAN KAEDAH}

Analisis ini dijalankan ke atas lima model korona jenis molar (geraham) dengan ketebalan yang berasingan iaitu $0.5,0.6,0.7,0.8$ dan $0.9 \mathrm{~mm}$. Parameter ketebalan korona ini diuji berdasarkan kajian terdahulu oleh Jang et al. (2011) dan Nakamura et al. (2015) yang mendakwa ketebalan bagi korona zirkonia komersial yang disarankan oleh pembuat atau pengilang adalah antara 0.6 hingga 0.8 $\mathrm{mm}$ bagi mengelakkan masalah penyerpihan berlaku. Sementara itu, kajian oleh Ban (2008) pula mendakwa julat ketebalan antara 0.5 sehingga $1.0 \mathrm{~mm}$ memberikan nilai lut cahaya yang diterima bagi restorasi korona zirkonia. Oleh itu, julat ketebalan zirkonia antara 0.5 hingga 0.9 $\mathrm{mm}$ telah dipilih untuk kajian ini.

\section{PENGHASILAN MODEL KORONA 3D MENGGUNAKAN} CAD

Sebelum analisis FEM dijalankan, model korona 3 dimensi (3D) dengan reka bentuk berbantu komputer (CAD) perlu dihasilkan terlebih dahulu melalui proses imbasan pada model gigi sebenar. Proses imbasan dilakukan menggunakan alat pengimbas tomografi berkomputer (CT Scan) (Freedom UHD DOF) yang mampu menjana geometri yang sempurna dan meminimumkan risiko kesilapan semasa simulasi FEM. Kaedah imbasan CT-Scan ini digunakan kerana ia membenarkan pembentukan model 3D untuk objek yang kecil dan bergeometri kompleks seperti gigi dan implan, serta tidak akan merosakkan bahan uji kaji (Della et al. 2013). Reka bentuk ketebalan bagi setiap lima model korona dalam bentuk 3D CAD kemudian dilaraskan mengikut parameter ketebalan yang telah ditetapkan iaitu $0.5-0.9 \mathrm{~mm}$.

\section{ANALISIS TERMA MELALUI SIMULASI FEM}

Kesemua model korona 3D CAD diimport ke perisian ANSYS Workbench 19.2 untuk menjalani simulasi FEM secara analisis terma. Bahan untuk model korona dalam kajian ditetapkan sebagai zirkonia monolitik, oleh itu maklumat data sifat bahan zirkonia berdasarkan kajian Nakamura et al. (2015) seperti dalam Jadual 1 dimuat masuk ke dalam perisian. Apabila model korona dalam bentuk 3D terpapar pada skrin, terdapat tiga komponen penting yang perlu ditetapkan iaitu saiz jejaring, keadaan sempadan dan penyelesaian yang dikehendaki. Saiz jejaring merupakan satu komponen yang sangat penting dalam FEM kerana ketepatan kajian dan jangka masa penyelesaian analisis bergantung kepadanya. Saiz jejaring boleh ditetapkan melalui saiz unsur. Apabila saiz jejaring meningkat, jangka masa penyelesaian analisis FEM menjadi semakin pantas namun ketepatan hasil kajian semakin menurun. Ujian penumpuan jejaring perlu dilakukan untuk mengenal pasti purata nilai saiz jejaring yang paling sesuai berdasarkan graf yang dihasilkan. Ujian ini dilakukan sebelum simulasi FEM dijalankan pada analisis terma ini. Parameter perubahan suhu pula ditetapkan antara 5 hingga $55^{\circ} \mathrm{C}$ yang merupakan purata suhu di dalam persekitaran mulut dan ia dilakukan berdasarkan selang masa yang ditetapkan kepada lima model 3D gigi. Perubahan suhu ini akan mempengaruhi nilai pengembangan terma korona dan tekanan Von Mises apabila dikenakan beban.

JADUAL 1. Sifat mekanik bahan zirkonia

\begin{tabular}{lc}
\hline \multicolumn{1}{c}{ Sifat mekanik } & Nilai \\
\hline Modulus anjal, GPa & 230.60 \\
Nisbah Poisson's & 0.3 \\
Ketumpatan, kgm $^{-3}$ & 6010 \\
\hline
\end{tabular}

Sumber: Nakamura et al. 2015

\section{ANALISIS BEBAN MEKANIK MELALUI SIMULASI FEM}

Analisis beban mekanik melalui simulasi FEM dilakukan dengan menetapkan keadaaan sempadan dan kekangan pada model tersebut. Hal ini disebabkan model daripada analisis terma digunakan pada analisis ini. Setiap model korona dikenakan enam darjah bebanan iaitu 300, 400, 500, 600, 700 dan $800 \mathrm{~N}$ secara berasingan. Nilai beban yang dikenakan ini adalah berdasarkan julat nilai beban bagi lelaki dan wanita ketika mengunyah. Setiap nilai bebanan dan sokongan tetap yang dikenakan pada model korona ditetapkan seperti yang ditunjukkan dalam Rajah 1(a) dan 1(b). Kedua-dua komponen tersebut boleh dikenakan sama ada pada permukaan model atau pada keseluruhan model tersebut. Sokongan tetap telah disetkan pada bahagian bawah korona manakala lima titik beban dikenakan pada permukaan oklusi korona iaitu di bahagian atas. Hal ini bagi mensimulasikan keadaan sebenar daya kunyahan bertindak semasa proses kunyahan berlaku. Di akhir proses simulasi, tegasan Von Mises pada seluruh permukaan korona akan membantu dalam mengenal pasti 
kawasan yang menerima beban maksimum paling tinggi. Manakala, ubah bentuk sepenuhnya pula akan menentukan sama ada simulasi ini memberi kesan terhadap kekuatan mekanik korona atau tidak.
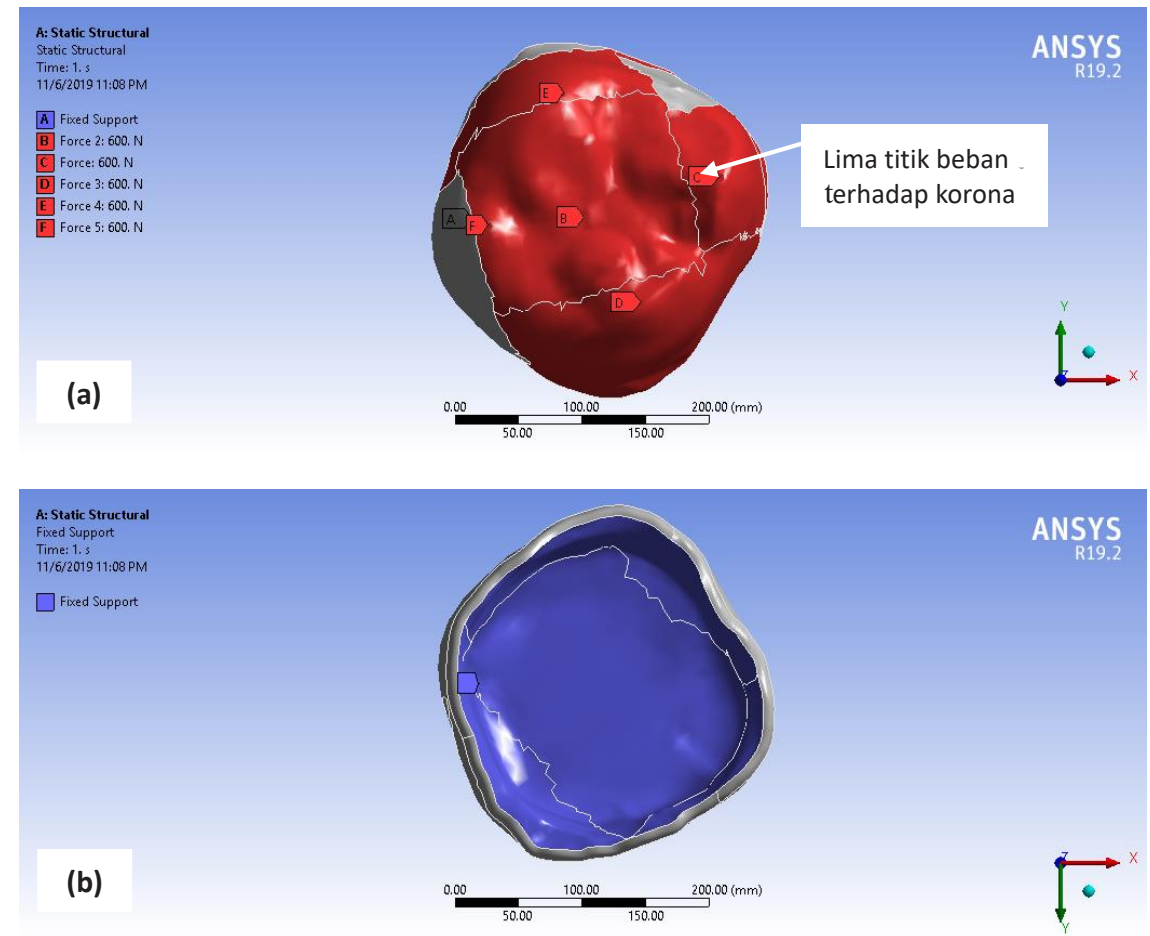

RAJAH 1. (a) Lima titik tekanan beban dikenakan pada permukaan oklusi korona zirkonia dan (b) kedudukan sokongan tetap pada permukaan bawah korona zirkonia

\section{HASIL DAN PERBINCANGAN \\ UJIAN PENUMPUAN JEJARING}

Ujian penumpuan jejaring telah dilakukan ke atas model korona dengan ketebalan $0.5 \mathrm{~mm}$ bagi mengenal pasti purata nilai saiz jejaring yang paling sesuai. Hasil ujian dipaparkan dalam Jadual 2. Apabila saiz unsur jejaring semakin kecil, jumlah unsur dan jumlah nod akan semakin bertambah. Pertambahan jumlah tersebut meningkatkan ketepatan keputusan kajian namun jangka masa penyelesaian analisis akan bertambah sekiranya saiz unsur jejaring semakin kecil.

JADUAL 2. Ujian penumpuan jejaring

\begin{tabular}{cccc}
\hline $\begin{array}{c}\text { Saiz unsur } \\
(\mathrm{mm})\end{array}$ & $\begin{array}{c}\text { Tekanan Von Mises maksimum } \\
(\mathrm{MPa})\end{array}$ & Jumlah unsur & Jumlah nod \\
\hline 4.0 & 151.41 & 41625 & 72311 \\
3.5 & 158.50 & 52195 & 90205 \\
3.0 & 197.71 & 65675 & 113360 \\
2.5 & 173.08 & 89820 & 154507 \\
2.0 & 192.26 & 131101 & 224505 \\
\hline
\end{tabular}


Perubahan nilai tekanan Von Mises berdasarkan jumlah unsur telah diplotkan seperti pada Rajah 2. Perubahan nilai tekanan Von Mises mencapai titik optimum terhadap pertambahan jumlah unsur. Keputusan ini menunjukkan peningkatan jumlah unsur jejaring meningkatkan ketepatan hasil simulasi sehingga mencapai titik kestabilan yang optimum (Bramanti et al. 2017). Berdasarkan kajian terdahulu oleh Dal Piva et al. (2018), beliau telah menggunakan nilai purata unsur dalam ujian penumpuan jejaring untuk digunakan dalam simulasi FEM. Justeru, dalam kajian ini nilai purata saiz unsur jejaring telah digunakan iaitu sebanyak $3 \mathrm{~mm}$ untuk analisis FEM bagi mendapatkan keputusan yang lebih tepat dengan masa simulasi yang optimum.

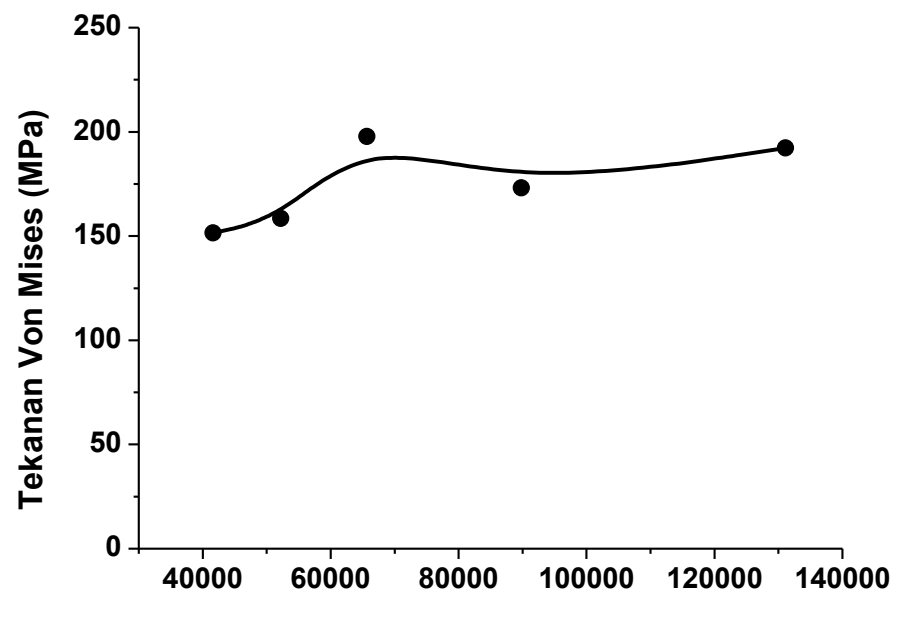

Jumlah unsur

RAJAH 2. Pengaruh jumlah unsur terhadap tekanan Von Mises

\section{PERBANDINGAN TEKANAN VON MISES MAKSIMUM DENGAN KETEBALAN BERBEZA UNTUK NILAI BEBAN BERBEZA}

Perbandingan nilai tekanan Von Mises apabila dikenakan beban pada ketebalan korona yang berbeza telah diplot sebagai carta palang pada Rajah 3. Berdasarkan keputusan tersebut, ketebalan korona didapati telah mempengaruhi nilai tekanan Von Mises semasa simulasi beban dan suhu dikenakan. Selain itu, bacaan tekanan Von Mises yang direkodkan bagi setiap pertambahan beban didapati agak konsisten untuk setiap ketebalan. Hal ini menunjukkan nilai beban mempunyai faktor yang kurang signifikan terhadap nilai tekanan Von Mises bagi ketebalan yang sama. Nilai tekanan Von Mises tertinggi dicatatkan pada ketebalan korona $0.6 \mathrm{~mm}$ dan diikuti oleh $0.7 \mathrm{~mm}$. Hal ini menunjukkan model korona dengan ketebalan $0.6 \mathrm{~mm}$ dalam kajian ini menerima tekanan yang tertinggi dan berisiko untuk mengalami kegagalan struktur berbanding model korona pada ketebalan yang lain.
Secara teorinya, peningkatan ketebalan korona akan mengurangkan kadar penumpuan tekanan yang berlaku disebabkan terdapat struktur yang lebih besar untuk tekanan disebarkan (Anami et al. 2015). Dalam kata lain, kekuatan korona akan meningkat dengan peningkatan ketebalan korona (Lan et al. 2015). Namun begitu, corak bacaan tekanan Von Mises yang diperoleh dalam kajian ini didapati tidak begitu selari dengan kenyataan tersebut. Hal ini dapat dilihat melalui bacaan tekanan Von Mises pada ketebalan $0.5 \mathrm{~mm}$ yang mana jauh lebih rendah daripada ketebalan 0.6 dan $0.7 \mathrm{~mm}$, begitu juga bacaan tekanan $0.9 \mathrm{~mm}$ yang dilihat lebih tinggi daripada ketebalan 0.8 apabila beban yang dikenakan meningkat lebih daripada 500N. Menurut Jager et al. (2005), hal ini terjadi apabila berlaku sedikit perubahan pada permukaan oklusi yang mempunyai ketebalan korona yang tidak seragam semasa beban dikenakan. Perubahan permukaan oklusi ini berkait rapat dengan sifat pengembangan terma zirkonia apabila terdapat perubahan suhu iaitu sama ada permukaan 
oklusi tersebut mengecut atau mengembang dan seterusnya mempengaruhi nilai tekanan yang bertindak (Jager et al. 2005).

Ketidakselarian pada bacaan tekanan Von Mises dalam keputusan kajian ini juga disebabkan faktor kedudukan beban mekanik yang dikenakan ke atas permukaan oklusi untuk setiap model korona masingmasing adalah berbeza. Kajian ini dilakukan berdasarkan kajian oleh Porojan et al. (2017) yang mengenakan lima titik beban pada permukaan oklusi. Namun dalam kajian beliau, lokasi titik beban diletakkan khusus pada permukaan oklusi. Hal ini menyebabkan kesan akibat beban yang dikenakan berbeza berbanding kajian beliau. Kajian oleh Ha et al. (2016) yang meletakkan lapan titik beban pada permukaan oklusi korona dengan lokasi tidak khusus juga menunjukkan keputusan hasil yang tidak seragam selari dengan kajian ini. Oleh itu, hasil keputusan seperti nilai tekanan Von Mises berbeza berdasarkan lokasi titik beban yang diletakkan.

Selain itu, faktor lain yang boleh menyebabkan keputusan ini berlaku adalah kaedah yang digunakan untuk menghasilkan geometri korona. Dalam kajian ini, kaedah imbasan tomografi berkomputer (CT Scan) digunakan kerana kelebihan kaedah ini seperti dapat menghasilkan geometri yang mempunyai resolusi yang tinggi serta mempunyai struktur yang lengkap dan menyerupai gigi sebenar. Namun, kaedah ini bergantung kepada pengalaman dan pengetahuan pengendali alat proses imbasan seperti masa pendedahan dan pembinaan semula imej untuk 3D CAD yang mana boleh berlaku ralat dan memberi kesan kepada hasil keputusan (Della et al. 2013).

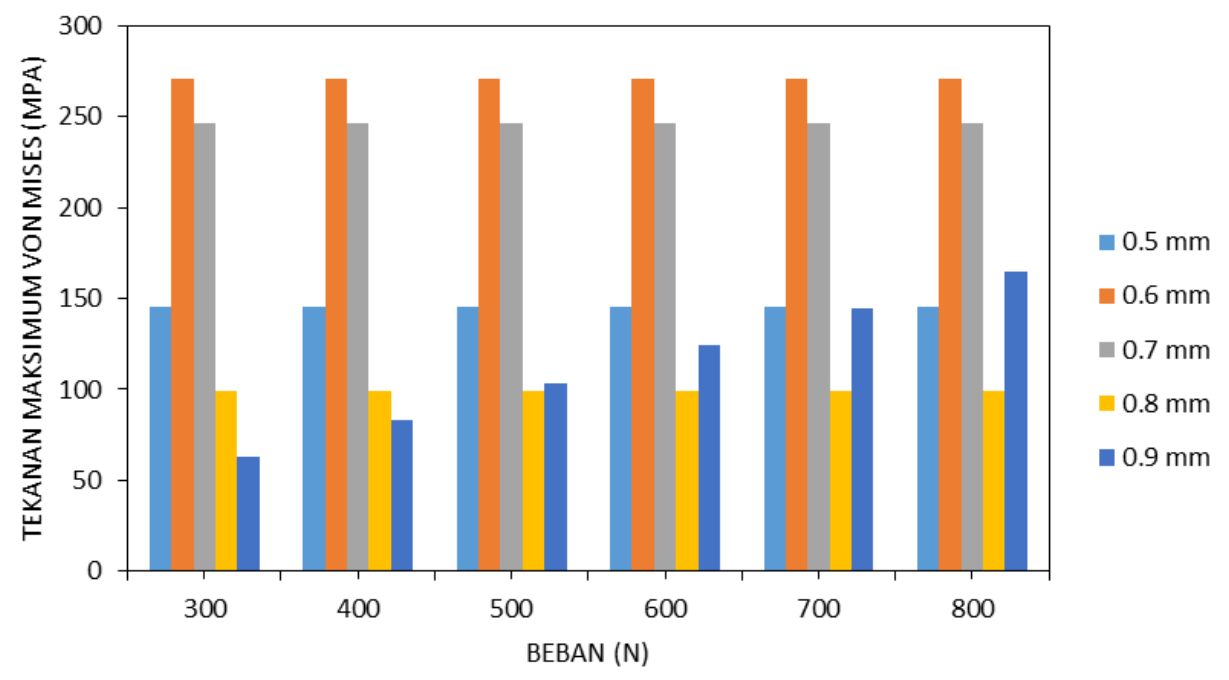

RAJAH 3. Perbandingan nilai tekanan Von Mises pada beban dan ketebalan korona yang berbeza

\section{PERUBAHAN NILAI UBAH BENTUK, TEKANAN VON} MISES DAN TEKANAN UTAMA

Analisis untuk perubahan nilai ubah bentuk, tekanan Von Mises dan tekanan utama dilakukan untuk setiap ketebalan korona zirkonia monolitik iaitu 0.5, 0.6, 0.7, 0.8 dan $0.9 \mathrm{~mm}$. Setiap model korona zirkonia monolitik dikenakan beban 300, 400, 500, 600, 700 dan $800 \mathrm{~N}$ iaitu julat beban aktiviti pengunyahan di bahagian permukaan oklusi korona. Berdasarkan Jadual 3, nilai tekanan maksimum Von Mises semakin meningkat apabila beban semakin meningkat. Peningkatan ini juga berlaku untuk nilai tekanan utama. Perubahan ini dapat dilihat untuk kesemua nilai beban yang dikenakan terhadap model dengan ketebalan $0.5 \mathrm{~mm}$. Hasil keputusan ini menunjukkan bahawa peningkatan nilai beban pada korona meningkatkan risiko kegagalan korona zirkonia monolitik. Bagi nilai ubah bentuk, perubahan yang berbeza dapat dilihat iaitu semakin bertambah nilai beban semakin berkurang nilai ubah bentuk. 
JADUAL 3. Perbandingan tekanan Von Mises dengan beban yang dikenakan pada ketebalan korona $0.5 \mathrm{~mm}$

\begin{tabular}{cccc}
\hline $\begin{array}{c}\text { Beban } \\
(\mathrm{N})\end{array}$ & $\begin{array}{c}\text { Ubah bentuk } \\
(\mathrm{mm})\end{array}$ & $\begin{array}{c}\text { Tekanan Von Mises maksimum } \\
(\mathrm{MPa})\end{array}$ & $\begin{array}{c}\text { Tekanan utama } \\
(\mathrm{MPa})\end{array}$ \\
\hline 300 & 0.013111 & 145.04 & 40.15 \\
400 & 0.013111 & 145.05 & 40.16 \\
500 & 0.013109 & 145.06 & 40.16 \\
600 & 0.013108 & 145.07 & 40.16 \\
700 & 0.013108 & 145.08 & 40.17 \\
800 & 0.013107 & 145.09 & 40.17 \\
\hline
\end{tabular}

Analisis yang lebih jelas boleh dilakukan berdasarkan hasil keputusan simulasi daripada ANSYS Workbench 19.2 kepada korona zirkonia monolitik. Perisian ANSYS Workbench 19.2 memaparkan keputusan simulasi dalam bentuk skala berwarna iaitu daripada warna biru untuk nilai minimum sehingga warna merah untuk nilai maksimum (Bramanti et al. 2017). Berdasarkan skala tersebut, kawasan yang menerima tekanan minimum dan maksimum dapat diperoleh daripada simulasi FEM. Tekanan Von Mises adalah penunjuk kepada penyebaran tekanan terhadap keseluruhan korona manakala nilai tekanan utama adalah nilai tekanan maksimum sebelum ubah bentuk berlaku. Rajah 4 menunjukkan kawasan yang paling tinggi menerima tekanan adalah di bahagian permukaan oklusi dengan beban mekanik dikenakan dan di bahagian serviks korona iaitu di bahagian berdekatan dengan sokongan tetap.
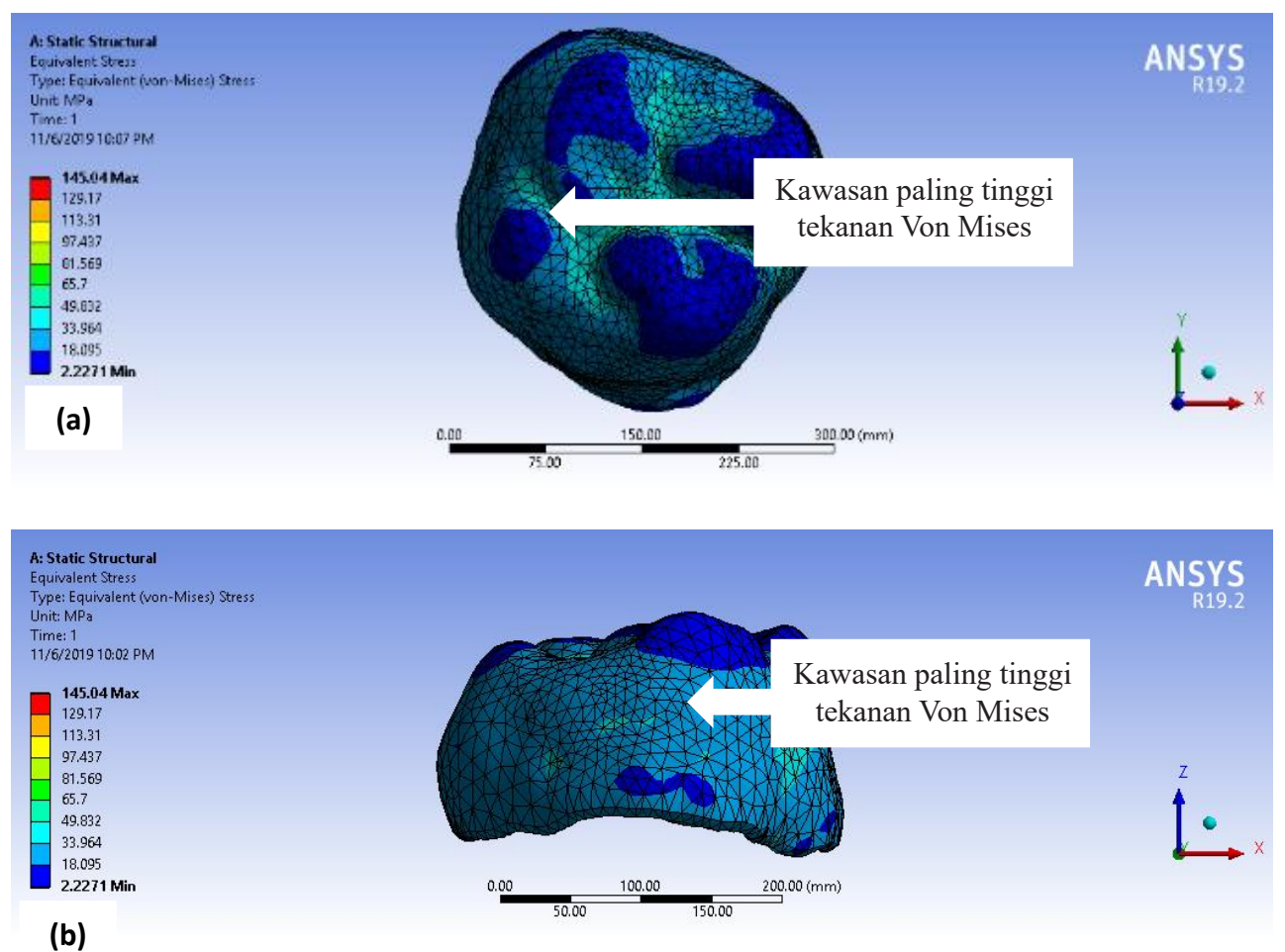

RAJAH 4. (a) Pandangan atas dan (b) pandangan sisi tekanan Von Mises pada beban $300 \mathrm{~N}$ dan ketebalan korona $0.5 \mathrm{~mm}$ 
Analisis tekanan utama untuk model korona monolitik zirkonia pula dapat dilihat seperti ditunjukkan dalam Rajah 5(a). Berdasarkan rajah tersebut, kawasan yang menerima tekanan agak seragam untuk keseluruhan pada permukaan kawasan korona manakala kawasan yang menerima tekanan utama paling tinggi adalah di bahagian serviks korona iaitu berdekatan dengan sokongan tetap. Rajah 5(b) dan 5(c) pula menunjukkan hasil simulasi FEM untuk analisis ubah bentuk. Berdasarkan rajah tersebut, kawasan yang mempunyai nilai ubah bentuk paling tinggi adalah pada kawasan permukaan oklusi iaitu pada kawasan yang menerima beban. Hal ini menunjukkan bahawa kawasan tersebut berisiko untuk gagal terlebih dahulu.

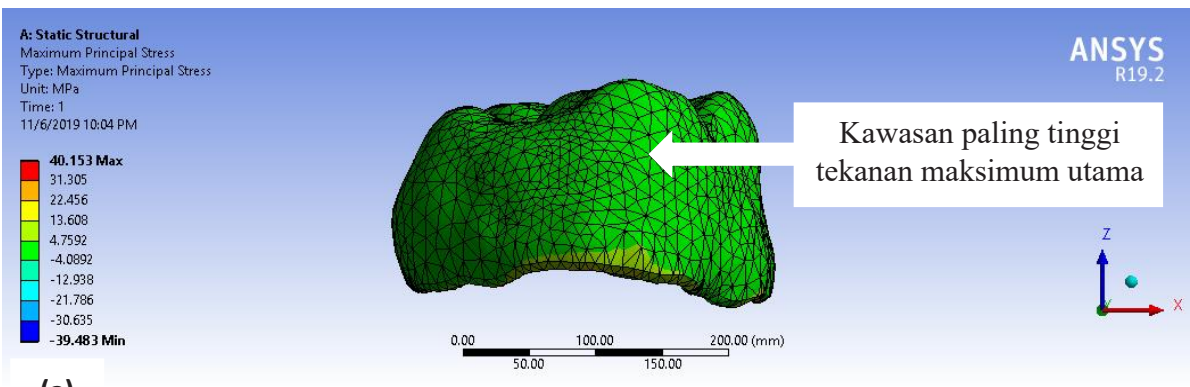

(a)
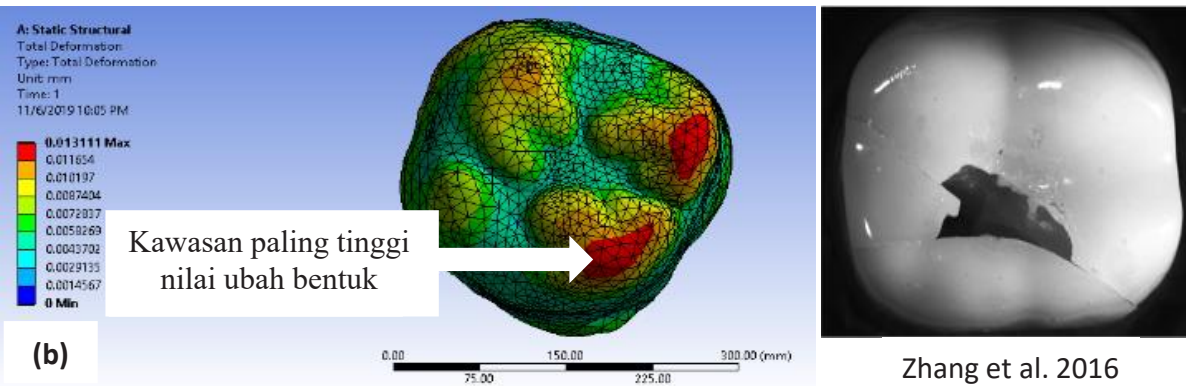

Zhang et al. 2016

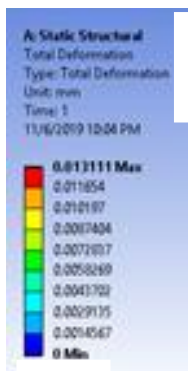

Kawasan paling tinggi nilai ubah bentuk

(c)
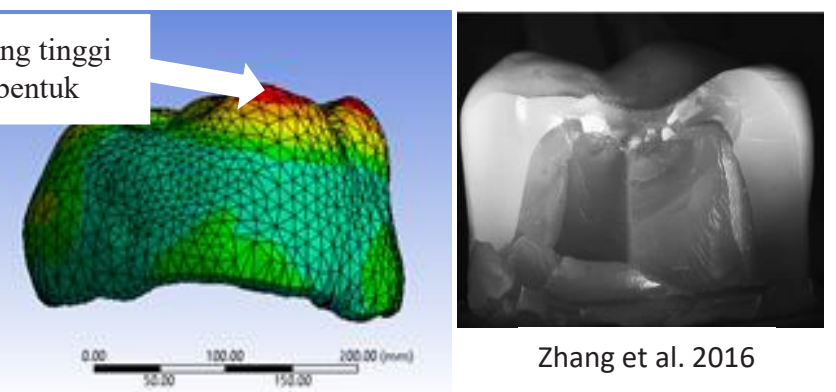

Zhang et al. 2016

RAJAH 5. (a) Tegasan utama maksimum pada beban $300 \mathrm{~N}$, (b) ubah bentuk pada beban $300 \mathrm{~N}$ dari pandangan atas dan (c) pandangan sisi

Berdasarkan keputusan analisis ubah bentuk, penyebaran tekanan dilihat menunjukkan keseragaman yang hampir serupa. Kawasan yang menerima nilai tekanan Von Mises yang tinggi menunjukkan kawasan di mana keretakan korona bermula. Penyelidikan terdahulu mendapati semakin tinggi ketebalan korona semakin kurang penumpuan tekanan yang terbentuk oleh kerana ruang kawasan yang lebih besar untuk tekanan disebarkan (Anami et al. 2015). Hasil simulasi FEM juga menunjukkan kawasan yang menerima paling tinggi 
nilai tekanan Von Mises dan tekanan utama adalah di bahagian serviks dan permukaan oklusi korona manakala nilai ubah bentuk pada permukaan oklusi. Hasil keputusan ini selari dengan kajian yang dilakukan oleh Zhang et al. (2016). Dalam kajian beliau, beban dikenakan kepada permukaan korona sehingga korona gagal atau retak. Berdasarkan hasil kajian beliau, keretakan berpunca daripada bahagian serviks dan permukaan oklusi yang dikenakan beban seperti yang ditunjukkan pada Rajah 5 .

\section{PERBANDINGAN KEPUTUSAN SIMULASI DENGAN KAJIAN TERDAHULU}

Keputusan kajian ini dibandingkan dengan kajian yang dilakukan oleh Nakamura et al. (2018) seperti dipaparkan dalam Jadual 4. Tekanan Von Mises dalam kajian ini dilihat lebih rendah berbanding Nakamura et al. (2018) disebabkan model korona zirkonia yang digunakan oleh beliau mempunyai lapisan komposit resin yang digabungkan kepada korona zirkonia. Perbezaan ciri mekanikal seperti modulus anjal, pengembangan terma dan nisbah Poisson antara lapisan komposit dan korona zirkonia telah menyebabkan tekanan Von Mises yang tinggi untuk kajian tersebut. Hal ini menunjukkan korona zirkonia monolitik mempunyai kekuatan yang lebih tinggi berbanding korona dwilapisan.

JADUAL 4. Perbandingan hasil kajian

\begin{tabular}{lccc}
\hline \multicolumn{1}{c}{ Parameter } & Kajian ini & Nakamura et al. (2018) & Porojan et al. (2017) \\
\hline Bahan & Zirkonia monolitik & Zirkonia komposit resin & Zirkonia lapisan venir \\
\hline Ketebalan korona (mm) & 0.5 & 0.5 & 0.5 \\
Beban (N) & 300 & 300 & 250 \\
Perubahan suhu & $50^{\circ} \mathrm{C}$ & $50^{\circ} \mathrm{C}$ & Tiada \\
Tekanan Von Mises (MPa) & 145.08 & 285.00 & Tiada \\
Tekanan maksimum utama & 40.15 & Tiada & 30.74 \\
$(\mathrm{MPa})$ & & & 3
\end{tabular}

Seterusnya, perbandingan dilakukan dengan kajian yang tidak mengambil kira perubahan suhu persekitaran oral. Kajian oleh Porojan et al. (2017) dilakukan terhadap korona zirkonia dengan ketebalan seragam $0.5 \mathrm{~mm}$ serta lima titik beban sebanyak 250 N. Berdasarkan Jadual 4, nilai tekanan maksimum utama pada kajian tersebut adalah $30.74 \mathrm{MPa}$ manakala tekanan maksimum utama bagi kajian ini pada ketebalan $0.5 \mathrm{~mm}$ adalah $40.15 \mathrm{MPa}$. Dengan ketiadaan perubahan suhu, sifat pengembangan terma zirkonia tidak akan memberi kesan kepada nilai tekanan utama kerana tiada pengecutan atau pengembangan pada korona. Walaupun beban yang dikenakan terhadap model zirkonia dalam kajian ini adalah lebih tinggi berbanding kajian Porojan et al. (2017), nilai tekanan maksimum yang dicapai dalam kajian ini dilihat lebih tinggi berbanding kajian beliau. Oleh itu, kajian ini menunjukkan keputusan tekanan maksimum yang lebih baik berbanding kajian oleh Porojan et al.
(2017) yang tidak mengambil kira keadaan sebenar persekitaran mulut yang terdedah kepada perubahan suhu.

Kajian yang dilakukan oleh Porojan et al. (2017) dilaksanakan dengan beberapa perubahan reka bentuk geometri pada korona seperti keseragaman ketebalan dan bentuk pada bahagian serviks korona. Manakala, kajian ini membahagikan nilai tekanan kepada tiga bahagian iaitu bahagian dentin, venir dan korona zirkonia. Tekanan maksimum utama pada kajian Porojan et al. (2017) untuk korona zirkonia lebih rendah kerana korona yang digunakan adalah korona dwilapisan iaitu dengan lapisan venir. Dalam kajian tersebut, nilai tekanan utama pada lapisan venir adalah $46.59 \mathrm{MPa}$ iaitu lebih tinggi daripada korona zirkonia monolitik. Oleh itu, tekanan lebih tertumpu pada lapisan venir kerana lapisan ini yang menerima beban dan risiko keretakan lebih tinggi di kawasan tersebut. 


\section{KESIMPULAN}

Kajian prestasi korona zikonia monolitik dengan menggunakan kaedah unsur terhingga telah dijalankan dengan menfokuskan analisis prestasi mekanik korona gigi zirkonia monolitik pada ketebalan korona yang berbeza untuk analisis kelesuan mekanik dengan perubahan suhu dalam persekitaran mulut. Objektif ini dicapai melalui analisis FEM serta perbandingan hasil keputusan dengan kajian terdahulu serta membandingkan nilai beban yang dikenakan kepada setiap ketebalan dari segi tekanan Von Mises, tekanan maksimum utama dan ubah bentuk. Hasil simulasi mendapati, ketebalan korona 0.8 dan $0.9 \mathrm{~mm}$ mencatatkan tekanan Von Mises yang terendah berbanding ketebalan yang lain. Hasil simulasi juga menunjukkan bahagian korona zirkonia monolitik yang menerima tekanan paling tinggi adalah di bahagian permukaan oklusi iaitu permukaan yang menerima beban mekanik dan bahagian serviks korona iaitu bahagian berdekatan dengan sokongan tetap. Walau bagaimanapun, ketebalan minimum $0.5 \mathrm{~mm}$ masih mampu menahan beban dan perubahan suhu yang dikenakan tetapi mempunyai risiko keretakan dan kegagalan lebih tinggi berbanding ketebalan lain.

\section{PENGHARGAAN}

Penulis merakamkan penghargaan kepada Universiti Kebangsaan Malaysia atas tajaan projek ini melalui geran penyelidikan DIP-2018-025. Tidak lupa juga penulis pertama merakamkan penghargaan kepada pelajar sarjana Muhammad Sufiyan Amril yang sudi berkongsi ilmu dan tunjuk ajar sepanjang kajian ini dilaksanakan.

\section{RUJUKAN}

Aboras, M., Muchtar, A., Husna, C., Yahaya, N. \& Mah, J.C.W. 2019. Enhancement of the microstructural and mechanical properties of dental zirconia through combined optimized colloidal processing and cold isostatic pressing. Ceramics International 45(2): 1831-1836.

Amat, N.F., Muchtar, A., Yew, H.Z., Amril, M.S. \& Muhamud, R.L. 2020. Machinability of a newly developed pre-sintered zirconia block for dental crown applications. Materials Letters 261(15): 126996.

Amat, N.F., Muchtar, A., Amril, M.S., Ghazali, M.J. \& Yahaya, N. 2019. Effect of sintering temperature on the aging resistance and mechanical properties of monolithic zirconia. Journal of Materials Research and Technology 8(1): 1092-1101.

Amat, N.F., Muchtar, A., Amril, M.S., Ghazali, M.J. \& Yahaya, N. 2018. Preparation of presintered zirconia blocks for dental restorations through colloidal dispersion and cold isostatic pressing. Ceramic International 44(6): 6409-6416.

Anami, L.C., da Costa Lima, J.M., Corazza, P.H., Yamamoto, E.T.C., Bottino, M.A. \& Borges, A.L.S. 2015. Finite element analysis of the influence of geometry and design of zirconia crowns on stress distribution. Journal of Prosthodontics 24(2): 146-151.

Ban, S. 2008. Reliability and properties of core materials for all-ceramic dental restorations. Japanese Dental Science Review 44(1): 3-21.

Bramanti, E., Cervino, G., Lauritano, F., Fiorillo, L., D’Amico, C., Sambataro, S., Denaro, D., Famà, F., Ierardo, G., Polimeni, A. \& Cicciù, M. 2017. FEM and von mises analysis on prosthetic crowns structural elements: Evaluation of different applied materials. The Scientific World Journal 2017 (1029574): 1-7.

Carrabba, M., Keeling, A.J., Aziz, A., Vichi, A., Fabian-Fonzar, R., Wood, D. \& Ferrari, M. 2017. Translucent zirconia in the ceramic scenario for monolithic restorations: A flexural strength and translucency comparison test. Journal of Dentistry 60(2017): 70-76.

Dal Piva, A.M.D.O., Tribst, J.P.M., Borges, A.L.S., e Souza, R.O.D.A. \& Bottino, M.A. 2018. CAD-FEA modeling and analysis of different full crown monolithic restorations. Dental Materials 34(9): 1342-1350.

Daud, M.H.M., Yew, H.Z., Zaman, J.Q., Yahaya, N. \& Muchtar, A. 2017. Evaluation of shear bond strength of a novel nanozirconia and veneering ceramics. Ceramics International 43(1): 1272-1277.

Denry, I. \& Kelly, J.R. 2008. State of the art of zirconia for dental applications. Dental Materials 24(3): 299-307.

Flinn, B.D., Raigrodski, A.J., Mancl, L.A., Toivola, R. \& Kuykendall, T. 2017. Influence of aging on flexural strength of translucent zirconia for monolithic restorations. The Journal of Prosthetic Dentistry 117(2): 303-309.

Ha, S.R., Kim, S.H., Lee, J.B., Han, J.S., Yeo, I.S., Yoo, S.H. \& Kim, H.K. 2016. Biomechanical three-dimensional finite element analysis of monolithic zirconia crown with different cement thickness. Ceramics International 42(13): 14928-14936.

De Jager, N., Pallav, P. \& Feilzer, A.J. 2005. The influence of design parameters on the FEA-determined stress distribution in CAD - CAM produced all-ceramic dental crowns. Dental Materials 21(3): 242-251.

Jang, G.W., Kim, H.S., Choe, H.C. \& Son, M.K. 2011. Fracture strength and mechanics of dental ceramic crown with zirconia thickness. Procedia Engineering 10(2011): 15561560.

Kohorst, P., Dittmer, M.P., Borchers, L. \& Stiesch-Scholz, M. 2008. Influence of cyclic fatigue in water on the loadbearing capacity of dental bridges made of zirconia. Acta Biomaterialia 4(5): 1440-1447.

Lan, T.H., Liu, P.H., Chou, M.M.C. \& Lee, H.E. 2016. Fracture resistance of monolithic zirconia crowns with different occlusal thicknesses in implant prostheses. The Journal of Prosthetic Dentistry 115(1): 76-83.

Miura, S., Kasahara, S., Yamauchi, S. \& Egusa, H. 2018. Effect of finish line design on stress distribution in bilayer and monolithic zirconia crowns: A three-dimensional finite element analysis study. European Journal of Oral Sciences 126(2): 159-165. 
Mundhe, K., Jain, V., Pruthi, G. \& Shah, N. 2015. Clinical study to evaluate the wear of natural enamel antagonist to zirconia and metal ceramic crowns. The Journal of Prosthetic Dentistry 114(3): 358-363.

Nakamura, K., Ankyu, S., Nilson, F., Kanno, T., Niwano, Y., Steyern, P.V. \& Örtengren, U. 2018. Critical consideration on load-to-failure test for molithic zirconia molar crowns. Journal of the Mechanical Behavior of Biomedical Materials 87(2018): 180-189.

Nakamura, K., Harada, A., Inagaki, R., Kanno, T., Niwano, Y., Milleding, P. \& Ortengen, U. 2015. Fracture resistance of monolithic zirconia molar crowns with reduced thickness. Acta Odontologica Scandinavica 73(8): 602-608.

Nasrin, S., Katsube, N., Seghi, R.R. \& Rokhlin, S.I. 2018. Approximate relative fatigue life estimation methods for thin-walled monolithic ceramic crowns. Dental Materials 34(5): 726-736

Porojan, L., Topală, F., Porojan, S. \& Savencu, C. 2017. Effect of frame design and veneering material on biomechanical behavior of zirconia dental crowns veneered with overpressing ceramics. Dental Materials 36(3): 275-281.

Preis, V., Grumser, K., Schneider-Feyrer, S., Behr, M. \& Rosentritt, M. 2016. Cycle-dependent in vitro wear performance of dental ceramics after clinical surface treatments. Journal of the Mechanical Behavior of Biomedical Materials 53(2016): 49-58.
Rekow, E.D., Silva, N.R.F.A., Coelho, P.G., Zhang, Y., Guess, P. \& Thompson, V.P. 2011. Performance of dental ceramics: Challenges for improvements. Journal of Dental Research 90(8): 937-952.

Wakabayashi, N., Murakami, N. \& Takaichi, A. 2018. Handbook of mechanics of materials. In Current Applications of Finite Element Methods in Dentistry, edited by Hsueh, C.H. Singapore: Springer. pp. 1-29.

Wang, F., Takahashi, H. \& Iwasaki, N. 2013. Translucency of dental ceramics with different thicknesses. Journal of Prosthetic Dentistry 110(1): 14-20.

Zhang, Y., Mai, Z., Barani, A., Bush, M. \& Lawn, B. 2016. Fracture-resistant monolithic dental crowns. Dental Materials 32(3): 442-449.

Department of Mechanical and Manufacturing Engineering Faculty of Engineering and Built Environment

Universiti Kebangsaan Malaysia

43600 UKM Bangi, Selangor Darul Ehsan

Malaysia

*Pengarang untuk surat-menyurat; email: muchtar@ukm.edu.my

Diserahkan: 14 Jun 2020

Diterima: 11 September 2020 